\title{
Aromatase excess syndromeas a model for genomic disorder: identification of molecular bases and phenotypic determinants
}

\author{
Tsutomu Ogata ${ }^{1 *}$, Makio Shozu $^{3}$, Maki Fukami ${ }^{2}$ \\ From 7th APPES Biennial Scientific Meeting \\ Nusa Dua, Bali. 14-17 November 2012
}

Aromatase excess syndrome (AEXS) is a rare autosomal dominant disorder characterized by gynecomastia. Although chromosomal inversions leading to abnormal fusion between CYP19A1 coding exons and non-coding exons of neighboring genes have been identified in a few patients with AEXS, its molecular basis and clinical spectrum remain largely unknown. We studied 18 affected males from six unrelated families $A-F$, and found a heterozygous 79,156 bp tandem duplication involving seven of 11 non-coding CYP19A1 exons 1 in families A and B, a heterozygous 211,631 bp deletion involving exons 2-43 of DMXL2 and exons 5-10 of GLDN in family C, and a heterozygous 165,901 bp deletion involving exons 2-43 of DMXL2 in families D-F. Analysis of transcripts revealed that duplicated exons 1 at the distal non-physiological position can also function as transcription start sites, and that the two deletions produced the same chimeric mRNA constituted by DMXL2 exon 1 and CYP19A1 exons 2-10. Clinical features such as gynecomastia and elevated estradiol/testosterone ratios were milder in patients with duplications and deletions than in those with inversions. Furthermore, genotypephenotype correlations in patients with duplications, deletions, and inversions implies that phenotypic severity of AEXS is primarily determined by the expression pattern of CYP19A1 and the chimeric genes and by the structural property of the fused exons with a promoter function (i.e., the presence or absence of a natural translation start codon). The present study expands the genetic mechanism and phenotypic spectrum of AEXS, and provides novel models for genomic disorder leading to gain-of-function mutations. We also discuss on the

'Department of Pediatrics, Hamamatsu University School of Medicine, Hamamatsu, Japan

Full list of author information is available at the end of the article effect of estradiol on the hypothalamic-pituitary gonadotropin control.

\section{Authors' details}

'Department of Pediatrics, Hamamatsu University School of Medicine, Hamamatsu, Japan. ${ }^{2}$ Department of Reproductive Medicine, Graduate School of Medicine, Chiba University, Chiba, Japan. ${ }^{3}$ Department of Molecular Endocrinology, National Research Institute for Child Health and Development, Tokyo, Japan.

Published: 3 October 2013

\section{doi:10.1186/1687-9856-2013-S1-O20}

Cite this article as: Ogata et al: Aromatase excess syndromeas a model for genomic disorder: identification of molecular bases and phenotypic determinants. International Journal of Pediatric Endocrinology 2013 2013(Suppl 1):O20.
Submit your next manuscript to BioMed Central and take full advantage of:

- Convenient online submission

- Thorough peer review

- No space constraints or color figure charges

- Immediate publication on acceptance

- Inclusion in PubMed, CAS, Scopus and Google Scholar

- Research which is freely available for redistribution
C Biomed Central

\section{Biomed Central}

